\title{
EXPERIMENTAL MODEL FOR TREATMENT OF EXTENDED SPECTRUM BETALACTAMASE PRODUCING-KLEBSIELLA PNEUMONIAE
}

\author{
Modelo experimental de tratamento de sepse por Klebsiella pneumoniae produtora de betalactamase de amplo espectro
}

Paula Virginia Michelon TOLEDO ${ }^{1,2,6}$, Felipe Francisco TUON ${ }^{1,3,6}$, Larissa BAIL ${ }^{4}$,

Francine MANENTE ${ }^{4}$, Polliane ARRUDA ${ }^{1}$, Ayrton Alves ARANHA-JUNIOR ${ }^{1,5}$

From the 'Departamento de Medicina, Universidade Estadual de Ponta Grossa, Ponta Grossa, PR; ${ }^{2}$ Departamento de Medicina, Pontificia Universidade Católica do Paraná, Cunitiba, PR; 'Departamento de Saúde Comunitánia, Universidade Federal do Paraná, Curitiba, PR; ${ }^{4}$ Departamento de Farmácia e Bioquímica, Universidade Estadual de Ponta Grossa, Ponta Grossa; ${ }^{5}$ Programa de Pós-graduação em Clínica Cinúrgica, Universidade Federal do Paraná, Cunitiba; 'Programa de Pós-graduação em Medicina Intema, Universidade Federal do Paraná, Cunitiba, PR, ('Department of Mediaine, State University of Ponta Grossa, Ponta Grossa, PR; '2Department of Medicine, Catholic University of Paraná, Curitiba, PR; ${ }^{3}$ Department of Community Health, Federal University of Paraná, Cunitiba, PR; ${ }^{4}$ Department of Pharmacy and Biochemistry, State University of Ponta Grossa, Ponta Grossa, PR; ${ }^{5}$ Post-Graduate Program in Clinical Surgery, Federal University of Paraná, Cuntiba, PR; ${ }^{6}$ Post-Graduate Program in Intemal Mediaine, Federal University of Paraná, Cunitiba, PR), Brazil.

HEADINGS - Klebsiella pneumoniae. Sepsis. Models, animal.

\section{Correspondence:}

Paula Toledo

Email: paulavmtoledo@yahoo.com.br

Financial source: CAPES.

Conflicts of interest: none

Received for publication: 30/01/2014 Accepted for publication: 13/05/2014

DESCRTORES - Klebsiella pneumoniae. Sepse. Modelos animais.
ABSTRACT - Background: Animal models are useful to evaluate the efficacy of antimicrobials in experimental sepsis. Aim: To elucidate the steps of producing an experimental model for the treatment of extended-spectrum beta-lactamase (ESBL)-producing Klebsiella pneumoniae sepsis Methods: Several ESBL inoculums ranging from $1.5 \times 10^{9}$ colony-forming units per milliliter $(\mathrm{CFU} / \mathrm{mL})$ to $2.0 \times 10^{10} \mathrm{CFU} /$ $\mathrm{mL}$ were administered by peritoneal injection in adults Wistar rats. Outcomes and microbiological data of quantitative peritoneal and blood cultures were observed in untreated animals. Animals which received $2.0 \times 10^{10} \mathrm{CFU} / \mathrm{mL}$ inoculums were treated with single meropenem dose $(30 \mathrm{mg} / \mathrm{kg})$ after one hour and those which received $1.0 \times 10^{10} \mathrm{CFU} / \mathrm{mL}$ inoculums were treated immediately with three doses of meropenem $50 \mathrm{mg} / \mathrm{kg}$. Outcomes were observed for 24 hours after inoculation. Results: Solutions with $1.5 \times 10^{9}$ and $6.0 \times 10^{9} \mathrm{CFU} / \mathrm{mL}$ were not lethal within 24 hours. Inoculums of $1.0 \times 10^{10} \mathrm{CFU} / \mathrm{mL}$ were lethal in $80 \%$ and solutions with $2.0 \times 10^{10}$ $\mathrm{CFU} / \mathrm{mL}$ were lethal in $100 \%$ of animals. ESBL lethal sepsis $\left(1.0 \times 10^{10} \mathrm{CFU} / \mathrm{mL}\right)$ was treated immediately with $50 \mathrm{mg} / \mathrm{kg}$ of meropenem every eight hours for 24 hours and presented $40 \%$ mortality compared with $80 \%$ mortality of the control group $(p=0.033)$. Quantitative cultures of peritoneal fluid presented $10^{4} \mathrm{CFU} / \mathrm{mL}$ or less for treated animals compared to more than $10^{5}$ for untreated animals $(p=0.001)$. Conclusion: Inoculums of $1.0 \times 10^{10} \mathrm{CFU} / \mathrm{mL}$ achieved the best results to study a model of lethal sepsis and this model of treatment of carbapenem-susceptible Enterobacteriaceae can serve as control to further evaluation of treatment of carbapenemase-producing Enterobacteriaceae models.
RESUMO - Racional: Modelos animais são importantes para avaliar a eficácia de antimicrobianos e a validação do sítio de infecção e a carga bacteriana. Objetivo: Definir a concentração do inóculo bacteriano, a dose e o tempo de administração de antimicrobianos a fim de validar um modelo experimental para o tratamento de Klebsiella pneumoniae produtora de betalactamase de amplo espectro em sepse letal. Método: Inóculos de Klebsiella pneumoniae produtora de betalactamase de espectro estendido de $1,5 \times 10^{9}$ unidades formadoras

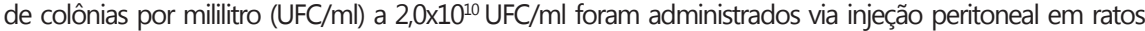
Wistar adultos. Sobrevida e dados microbiológicos de hemoculturas e culturas quantitativas de fluido peritoneal foram avaliados inicialmente em animais não tratados. Animais inoculados com 2,0x1010 UFC/

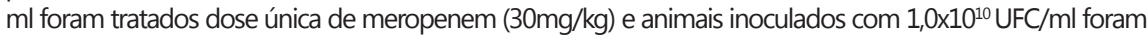
tratados imediatamente com meropenem $(50 \mathrm{mg} / \mathrm{kg}$ ) por 24 horas e os desfechos foram avaliados após 24 horas da inoculação. Resultados: Soluções com $1,5 \times 10^{9}$ e 6,0×10 UFC/ml não foram letais. Inóculos de $1,0 \times 10^{10} \mathrm{UFC} / \mathrm{ml}$ e de $2,0 \times 10^{10} \mathrm{UFC} / \mathrm{ml}$ foram letais em $80 \%$ e $100 \%$ dos animais respectivamente. Sepse letal $\left(1.0 \times 10^{10} \mathrm{CFU} / \mathrm{mL}\right) \mathrm{com}$ tratamento imediato e por 24 horas apresentou $40 \%$ de mortalidade, comparada com $80 \%$ nos controles $(p=0.033)$. Culturas quantitativas de fluido peritoneal apresentaram $\leq 10^{4} \mathrm{UFC} /$ $\mathrm{ml}$ enquanto que controles sem tratamento apresentaram $>10^{5} \mathrm{UFC} / \mathrm{ml}(\mathrm{p}=0.001)$. Conclusão: Modelo

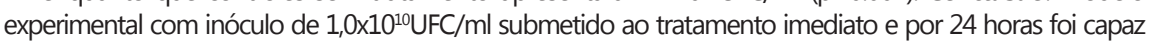
de avaliar resposta microbiológica e de sobrevida podendo ser modelo de embasamento e de controle para tratamento de sepse letal por Klebsiella pneumoniae produtora de carbapenemase.

\section{INTRODUCTION}

$T$ The incidence of carbapenemase-producing Enterobacteriaceae has increased and the ideal treatment has not been established. Some retrospective studies suggest an association of different drugs to improve

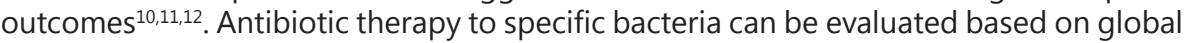
mortality, time to death and rate of microbiological cure. Considering these findings, an experimental model might be helpful to evaluate the combination of different drugs to treat carbapenemase-producing Enterobacteriaceae until clinical studies confirm the benefits of this approach. To study animal models on carbapenemase-producing Enterobacteriaceae, a treatment control of extended-spectrum betalactamase (ESBL)producing Klebsiella pneumonia must be validated.

Several animal models of peritonitis, pneumonia and thigh infection after imunossupression using Enterobacteriaceae were reviewed, but none defines a peritonitis 
model of ESBL-producing Klebsiella pneumoniae treatment with meropenem. Models of peritonitis in rats evaluated inoculums ranging from $10^{5}$ to $10^{10}$ colony-forming unit per milliliter (CFU/ $\mathrm{mL}$ ) of $E$. coli. Lethal sepsis was observed at higher inoculum concentrations $\left(10^{9} \text { to } 10^{10} \mathrm{CFU} / \mathrm{mL}\right)^{2,3,5}$. Non-lethal models were done with $10^{5}$ to $10^{8} \mathrm{CFU} / \mathrm{mL}$ inoculums ${ }^{1,13}$. Klebsiella pneumoniae was evaluated in peritonitis of neutropenic mice $\left(3 \times 10^{5} \mathrm{CFU} / \mathrm{mL}\right)^{4}$, thigh infection in neutropenic rats $\left(10^{6}\right.$ to $10^{8}$ $\mathrm{CFU} / \mathrm{mL})^{6,8}$ and pneumonia models in rats $\left(10^{6} \text { to } 10^{10} \mathrm{CFU} / \mathrm{mL}\right)^{7}$. Enterobacter spp. was also evaluated in a pneumonia model of $10^{10} \mathrm{CFU} / \mathrm{mL}^{9}$.

Klebsiella pneumoniae inoculum concentrations must be standardized to determine a sepsis model that might be able to evaluate the efficacy of antimicrobial therapy in preventing lethality serving as a control for treatment of carbapenem-resistant Klebsiella pneumoniae.

This study aims to describe the more adequate inoculum concentration to induce lethal but treatable sepsis. Timing and dose of antimicrobial therapy for ESBL peritoneal sepsis induced in non-neutropenic rats were evaluated.

\section{METHODS}

\section{Animals}

The experiment was performed with adult (20-24 week old) male and female Wistar rats weighting 200 $340 \mathrm{~g}$. Animals were maintained under artificial day-night cycles, adequate temperature $\left(22-24{ }^{\circ} \mathrm{C}\right)$ and humidity. The rats received a standard diet and water ad libitum. Animals were allowed to adapt to laboratory conditions for two days. The animal research ethics committee of the Universidade Estadual de Ponta Grossa approved the study. Fifty rats were included in the phases of this experiment.

Bacterial strain, inoculum production and sepsis induction ESBL-producing strain (ATCC 700603) was inoculated into Mueller-Hinton broth and incubated at $37^{\circ} \mathrm{C}$ for $24 \mathrm{~h}$ Colonies were suspended in sterile isotonic saline solution to form the inoculums.

To accurately measure the inoculum a densimeter (Densimat Biomerieux $®$ ) capable of measuring densities of 0.5 to $7.5 \mathrm{McF}$ arland was used to evaluate the inoculums of $1.5 \times 10^{9} \mathrm{CFU} / \mathrm{mL}$ which was obtained at 5 McFarland. To accurately measure more concentrated inoculums, spectrophotometry (Lambda 25 UV/Vis Spectrophotometer Perkin Elmer ( ) ) was performed at optic density of $625 \mathrm{~nm}$. Inoculums with $1.5 \times 10^{10}$ and $2.0 \times 10^{10} \mathrm{CFU} / \mathrm{mL}$ corresponded to solutions of barium chloride and sulfuric acid of 50 and 67 McFarland standards and the absorbencies of these solutions were 2.343 and 2.764 respectively. According to Beer-Lambert law, absorbencies over 0.890 are not accurate for measuring microorganism counts. After 1:20 dilution, inoculums with $1.5 \times 10^{10}$ and $2.0 \times 10^{10} \mathrm{CFU} / \mathrm{mL}$ presented absorbencies of 0.543 and 0.633 . Inoculums of $6.0 \times 10^{9} \mathrm{CFU} /$ $\mathrm{mL}$ and $1 \times 10^{10}$ were obtained by injection of $0.4 \mathrm{~mL}$ and 0.6 $\mathrm{mL}$ of $1.5 \times 10^{10} \mathrm{CFU} / \mathrm{mL}$ solution.

All inoculums were incubated at Mueller-Hinton and CFU were counted eight hours latter to confirm the concentration before animal injection.

Sepsis was induced by intra-peritoneal injection of the inoculum using a 26 gauge needle in the lower right abdomen. All the procedure was performed under aseptic conditions.

Inoculum lethality was defined by injection of $1.5 \times 10^{9}$ $\mathrm{CFU} / \mathrm{mL}$ solution in six animals, $6.0 \times 10^{9} \mathrm{CFU} / \mathrm{mL}$ in five, $1.0 \times 10^{10}$ $\mathrm{CFU} / \mathrm{mL}$ in ten animals and $2.0 \times 10^{10} \mathrm{CFU} / \mathrm{mL}$ in ten animals.

\section{Antimicrobial therapy}

Two groups of ESBL lethal sepsis were treated with meropenem (Astra-Zeneca $\left.{ }^{\circledR}\right)$. Twelve rats were inoculated with $2.0 \times 10^{10} \mathrm{CFU} / \mathrm{mL}$ and six of them were treated with one dose of meropenem $30 \mathrm{mg} / \mathrm{kg}$ after one hour of inoculation. Twenty animals were inoculated with $1.0 \times 10^{10} \mathrm{CFU} / \mathrm{mL}$ and ten were treated immediately with $50 \mathrm{mg} / \mathrm{kg}$ of meropenem every eight hours for 24 hours. Homogeneous distribution of animals by weight and sex were done in treated and untreated groups.

\section{Outcome evaluation}

The rate of lethality, length of survival, blood cultures positivity and quantitative peritoneal fluid and peritoneal tissue cultures were evaluated. Cultures were obtained aseptically.

Animals not presenting lethal sepsis after $24 \mathrm{~h}$ suffered euthanasia with lethal doses of xylazine and quetamine.

Blood cultures $(0.5-1.0 \mathrm{~mL})$ were collected through cardiac puncture after death or euthanasia and incubated in brain heart infusion broth.

Peritoneal fluid was obtained after laparotomy and injection of $5 \mathrm{~mL}$ of isotonic saline and aspiration. One microliter of this fluid was cultured in McConkey agar. Quantitative cultures were performed after 1:100 dilutions of the peritoneal solution in isotonic saline and incubation of $1 \mu \mathrm{L}$ in McConkey agar.

\section{Statistical analysis}

Continuous data were expressed as mean \pm standard deviation (SD), frequencies were expressed as percentages. Dichotomous variables were compared using MannWhitney test. Kruskal-Wallis test was used to evaluated hours of survival of the four untreated groups. Significance level was set at 0.05. All data were stored using the software Excel (Microsoft, New York, USA) and statistical analysis was performed using the software SPSS 16 (SPSS, Chicago, USA). Graphics and statistical analysis by Mann-Whitney were performed with GraphPad Prism 5.0 (GraphPad, La Jolla, USA).

\section{RESULTS}

ESBL solutions ranging from $1.5 \times 10^{9}$ to $2.0 \times 10^{10} \mathrm{CFU} /$ $\mathrm{mL}$ were evaluated. Solutions with $1.5 \times 10^{9} \mathrm{CFU} / \mathrm{mL}$ were not lethal in $100 \%$ of animals. Inoculums of $6.0 \times 10^{9}$ and $1.0 \times 10^{10} \mathrm{CFU} / \mathrm{mL}$ were lethal in $80 \%$ rats. Solutions with $2.0 \times 10^{10} \mathrm{CFU} / \mathrm{mL}$ were lethal in $100 \%$ of animals (Figure 1). ESBL lethal sepsis $\left(2.0 \times 10^{10} \mathrm{CFU} / \mathrm{mL}\right)$ was treated with meropenem one dose of $30 \mathrm{mg} / \mathrm{kg}$ after one hour of inoculation with no improvement on mortality. Other group of ESBL lethal sepsis $\left(1.0 \times 10^{10} \mathrm{CFU} / \mathrm{mL}\right)$ was treated immediately with $50 \mathrm{mg} / \mathrm{kg}$ of meropenem every eight hours for 24 hours presented $40 \%$ mortality, significantly lower than $80 \%$ mortality of the control group $(p=0.042$, Figure 2). Quantitative cultures of peritoneal fluid presented $10^{4} \mathrm{CFU} / \mathrm{mL}$ or less for treated animals compared to more than $10^{5}$ for untreated animals $(p=0.001$, Figure 3 )

\section{DISCUSSION}

Previous studies described models of peritoneal inoculums of $E$. coli between $10^{5}$ and $10^{10} \mathrm{CFU} / \mathrm{mL}$ to achieve lethal and non-lethal sepsis ${ }^{2,5,13}$. Recent models of neutropenic rats with thigh infection are performed with lower concentrated inoculums and usually do not evaluate mortality, only microbiologic efficacy ${ }^{8}$. Models with Klebsiella spp. are less frequent and must be validated. Here is described the standardization of a lethal model of peritonitis by ESBL-producing $K$. pneumoniae passible of treatment in non immunosuppressed rats. 


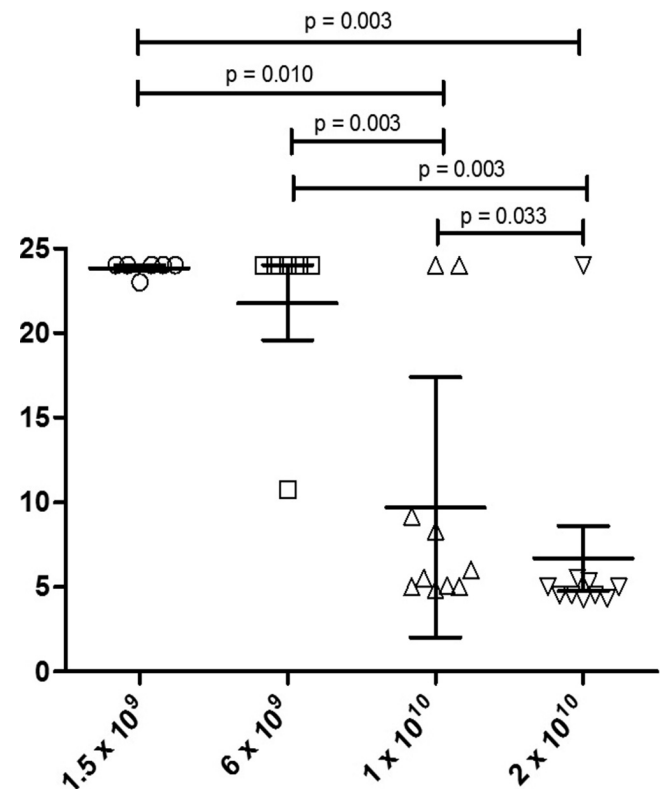

FIGURE 1 - Survival time in hours of untreated animals according to inoculum concentrations (CFU/ml)

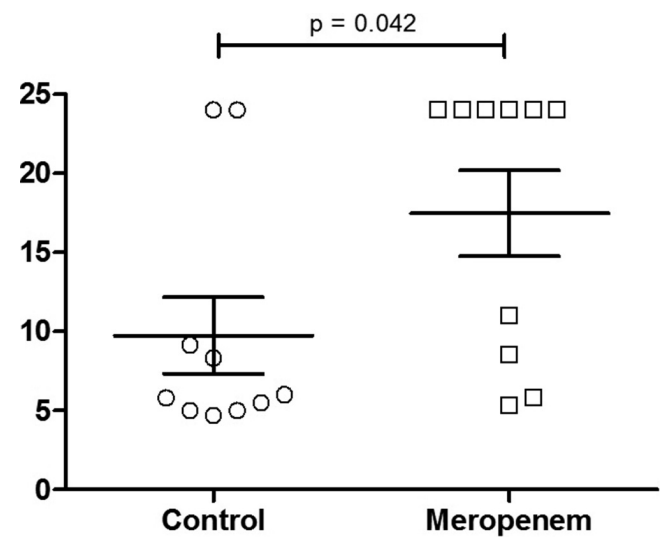

FIGURE 2 - Survival after $1.0 \times 10^{10} \mathrm{CFU} / \mathrm{mL}$ inocullum in untreated animals and treated imediatelly with higher meropenem dose

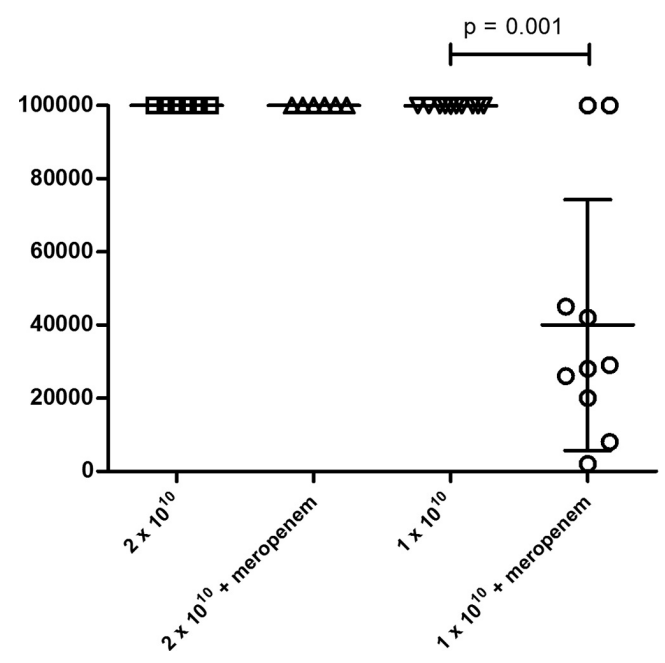

FIGURE 3 - Quantitative peritoneal cultures after treatment of peritonitis. $2.0 \times 10^{10} \mathrm{CFU} / \mathrm{mL}$ inocullum treated with lower meropenem single dose vs $1.0 \times 10^{10} \mathrm{CFU} / \mathrm{mL}$ inocullum treated imediatelly with higher meropenem dose

Solutions of $10^{8}$ and $10^{9} \mathrm{UFC} / \mathrm{mL}$ cause non-lethal sepsis in immunocompetent rats, which are useful to stratify antimicrobial dosing and compare antimicrobial efficacy on microbiological results, but are not ideal to compare antimicrobial efficacy on clinical outcomes. Was observed that a single antimicrobial dose after inoculation might not be adequate to differentiate treated and untreated animals. Furthermore, was also observed that inoculation of $2.0 \times 10^{10}$ $\mathrm{CFU} / \mathrm{mL}$ with no immediate treatment, cause lethal sepsis that may not be adequate to evaluate antimicrobial efficacy on survival, since most animals may die in spite of treatment.

Inoculums of more than $1.0 \times 10^{10}$ and less than $2.0 \times 10^{10}$ colony-forming units per milliliter, accurately measured by spectrophotometry, produce lethal sepsis. Immediate treatment after inoculation, administered for 24 hours permits to compared outcomes and microbiological samples of treated and untreated animals. The immediate antimicrobial infusion was based on previous studies ${ }^{2,5}$. Was thought that immediate infusion of antibiotic could reduce the bacterial burden, but both groups had positive cultures in the end of the experiment.

This study validates an animal model of sepsis which induced lethal peritonitis in the control group between six and 24 hours and the treated group had cultures with significantly fewer microorganisms. Data from quantitative cultures, length of survival and mortality can serve as a control to evaluate the treatment of carbapenemase-producing Enterobacteriaceae models.

\section{CONCLUSION}

Inoculums of $1.0 \times 10^{10} \mathrm{CFU} / \mathrm{mL}$ achieved the best results to study a model of lethal sepsis and this model of treatment of carbapenem-susceptible Enterobacteriaceae can serve as control to further evaluation of treatment of carbapenemaseproducing Enterobacteriaceae models.

\section{ACKNOWLEDGMENTS}

We would like to thank the Animal Laboratory staff.

\section{REFERENCES}

1. Bosscha K, Nieuwenhuijs VB, Gooszen AW, van DuijvenbodeBeumer $H$, Visser MR, Verweij WR, Akkermans L M. A standardised and reproducible model of intraabdominal infection and abscess formation in rats. Eur J Surg 2000; 166: 963-967.

2. Cirioni $O$, Giacometti $A$, Ghiselli $R$, Mocchegiani $F$, Fineo $A$, Orlando F, Del Prete MS, Rocchi M, Saba V, Scalise G.. Single-dose intraperitoneal magainins improve survival in a gram-negativepathogen septic shock rat model. Antimicrob Agents Chemother 2002; 46: 101-104.

3. Davis SD. Activity of gentamicin, tobramycin, polymyxin B, and colistimethate in mouse protection tests with Pseudomonas aeruginosa. Antimicrob Agents Chemother 1975; 8: 50-53.

4. Endimiani A, Hujer KM, Hujer AM, Pulse ME, Weiss WJ, Bonomo RA.. Evaluation of ceftazidime and NXL104 in two murine models of infection due to KPC-producing Klebsiella pneumoniae. Antimicrob Agents Chemother 2011; 55: 82-85.

5. Giacometti A, Cirioni O, Ghiselli R, Mocchegiani F, Paggi AM, Orlando F, Kamysz W, Kasprzykowski F, Mackiewicz Z, Scalise G, Saba V.. Therapeutic efficacy of intraperitoneal polymyxin B and polymyxin-like peptides alone or combined with levofloxacin in rat models of septic shock. J Antimicrob Chemother 2002; 49: 193-196.

6. Housman ST, Keel RA, Crandon JL, Williams G, Nicolau DP. Efficacy of human simulated exposures of ceftaroline against phenotypically diverse Enterobacteriaceae isolates. Antimicrob Agents Chemother 2012; 56: 2576-2580.

7. Kesteman AS, Ferran AA, Perrin-Guyomard A, Laurentie M, Sanders $\mathrm{P}$, Toutain $\mathrm{PL}$, Bousquet-Mélou A.. Influence of inoculum size and marbofloxacin plasma exposure on the amplification of resistant subpopulations of Klebsiella pneumoniae in a rat lung infection model. Antimicrob Agents Chemother 2009; 53: 4740-4748. 
8. Maglio D, Banevicius MA, Sutherland C, Babalola C, Nightingale $\mathrm{CH}$, Nicolau DP. Pharmacodynamic profile of ertapenem against Klebsiella pneumoniae and Escherichia coli in a murine thigh model. Antimicrob Agents Chemother 2005; 49: 276-280.

9. Mimoz O, Leotard S, Jacolot A, Padoin C, Louchahi K, Petitjean $\mathrm{O}$, Nordmann P.. Efficacies of imipenem, meropenem, cefepime, and ceftazidime in rats with experimental pneumonia due to a carbapenem-hydrolyzing beta-lactamase-producing strain of Enterobacter cloacae. Antimicrob Agents Chemother 2000; 44: 885-890.

10. Qureshi ZA, Paterson DL, Potoski BA, Kilayko MC, Sandovsky G, Sordillo E, Polsky B, Adams-Haduch JM, Doi Y. Treatment outcome of bacteremia due to KPC-producing Klebsiella pneumoniae: superiority of combination antimicrobial regimens. Antimicrob Agents Chemother 2012; 56: 2108-2113.
11. Tumbarello M, Viale P, Viscoli C, Trecarichi EM, Tumietto F, Marchese A, Spanu T, Ambretti S, Ginocchio F, Cristini F, Losito AR, Tedeschi $S$, Cauda R, Bassetti M.. Predictors of mortality in bloodstream infections caused by Klebsiella pneumoniae carbapenemaseproducing K. pneumoniae: importance of combination therapy. Clin Infect Dis 2012; 55: 943-950.

12. Tuon FF1, Rocha $\mathrm{JL}$, Toledo $\mathrm{P}$, Arend $\mathrm{LN}$, Dias $\mathrm{CH}$, Leite TM, Penteado-Filho SR, Pilonetto M, Zavascki AP. Risk factors for KPCproducing Klebsiella pneumoniae bacteremia. Braz J Infect Dis 2012; 16: 416-419.

13. Wandall DA, Arpi $M$, Wandall JH. A rat model of non-lethal bacterial infection. APMIS 1997; 105: 187-191. 